\title{
On the Need to Develop Professional Competences in Criminal Procedure and Criminalistics in Corrections Officers of the Federal Penitentiary Service of Russia
}

\author{
ALEKSANDR S. SHATALOV \\ Academy of the Federal Penitentiary Service of Russia, Ryazan, Russian \\ Federation
}

ORCID: https://orcid.org/0000-0001-9696-416X, e-mail: asshatalov@rambler.ru

\author{
ALEKSANDR V. AKCHURIN \\ Academy of the Federal Penitentiary Service of Russia, Ryazan, Russian \\ Federation
}

ORCID: https://orcid.org/0000-0003-1742-1162, e-mail: 79206310258@yandex.ru

\begin{abstract}
A bstract. The paper substantiates the idea that while performing law enforcement functions correctional institutions face the risks of illegal behavior on the part of those individuals who do not want to embark on the path of reformation. The most effective response to the facts of criminal acts committed by convicts is associated with the implementation of the principle of the inevitability of criminal punishment for such behavior. The speed of such a response is of paramount importance and depends on corrections officers themselves. The response can be effective only if officers of the Federal Penitentiary Service of Russia (FSIN Russia) use the full range of procedural and criminalistic tools at their disposal. Based on the analysis of the criminal procedure status of institutions, bodies and officials of FSIN Russia and the content of their functional responsibilities, we make an attempt to find out whether corrections officers need criminalistic knowledge. We identify the main areas in which corrections officers demand criminalistic knowledge. These include: law enforcement (for direct use in the implementation of criminal procedure powers, as well as for indirect use in the implementation of their main activities aimed at the execution of criminal penalties), education (for training personnel for penal institutions and bodies), and research (for further elaboration on the issues related to the investigation of prison offences).

Key words: correctional institutions; criminalistics; convicts; criminal process; prison-related crimes; investigation of crimes; Federal Penitentiary Service of Russia.
\end{abstract}

12.00.12 - Criminalistics; intelligence-gathering activities; forensic expertise.

For citation: Shatalov A.S., Akchurin A.V. On the need to develop professional competences in criminal procedure and criminalistics in corrections officers of the Federal Penitentiary Service of Russia. Penitentiary Science, 2020, vol. 14, no. 4 (52), pp. 570-576. DOI 10.46741/2686-9764-2020-14-4-570-576.

The state imposes compulsory measures on the subjects of legal relations who violate current legislation; from this viewpoint the penal system virtually closes the circuit of law enforcement agencies by exerting final impact on such individuals for the purpose of their reformation and recognition of the need to observe the norms established by the state. However, the implementation of correctional measures in relation to a particular individual does not mean the latter will immediately change their attitude toward society, state, and law. Quite often, while serving their criminal sentences, convicts do not seek to give up their routine filled up with illegal activities. Statistics of the Fed- eral Penitentiary Service of Russia (FSIN Russia) annually report about a thousand crimes committed by convicts in correctional facilities (in 2017 - 875 prison-related crimes were registered; in 2018 - 914; in 2019 - 1,015) [10]. Disciplinary measures applied to prison offenders do not usually have a long-term proper effect. On the contrary, convicts who are subject to disciplinary measures use them to gain certain authority in penal institutions.

The greatest effect on the illegal activities of convicts is exerted by the inevitability of criminal punishment for the committed criminal acts; $97.8 \%$ of the surveyed convicts noted that gaining freedom was the most significant motive for 
them to change their behavior ${ }^{1}$. Therefore, they are hit quite hard by any increase in the term of their imprisonment. In personal conversations, corrections officers of FSIN Russia point out that this factor may be important in the implementation of measures to overcome the illegal activities of persons held in institutions that ensure their isolation from society ${ }^{2}$.

However, in practice the potential of this seemingly effective measure cannot always be implemented by corrections officers of FSIN Russia. The problem of the current situation is multifaceted and controversial, but its essence, in our opinion, consists in the lack of awareness of the need to develop certain competencies in corrections officers that would allow them to act competently in a situation when convicts engage in illegal activity, in order to hold the latter criminally responsible [13].

The work of penal institutions and authorities is not only very specific, but also multidimensional. In addition to the enforcement of court sentences that have entered into force, it aims to reform convicted persons and prevent them from committing new crimes. All its employees are required to maintain the level of qualification necessary for the proper performance of their official duties. They also engage in professional training and (or) obtain additional professional education (Article 12 of Federal Law 197-FZ "On the service in the penal system of the Russian Federation and on introducing amendments in the RF Law "On institutions and bodies executing custodial penalties" of July 19, 2018). It is well-known that in some cases their activity goes beyond the scope of penal legislation. Quite often it is carried out in accordance with the requirements of the criminal procedure law and takes into account practical recommendations of domestic criminalistics, thus transforming into a purely cognitive, i.e. procedural and criminalistic activity in its essence. It is based on universal theoretical and methodological provisions that are typical of this activity as such, i.e. regardless of the territories and subjects that engage in it. However, this activity of the institutions and authorities of the penal system has its specific features that are reflected neither in the norms of the Criminal Procedure Code of the Russian Federation (hereinafter - RF

1 The survey was conducted in correctional institutions of the Republic of Tatarstan, Krasnoyarsk Krai, the Moscow, Tver and Ryazan oblasts in 2018-2020. A total of 126 convicts were interviewed.

2 The interviews were conducted with participation of the employees of correctional institutions of FSIN Russia who had graduated from the Academy of the Federal Penitentiary Service of Russia in 2017-2019. Staff of correctional institutions participated in a total of 31 interviews.
$\mathrm{CPC}$ ), nor in the departmental normative legal acts. Nevertheless, these features are described in detail in the specialized literature, since they have been actively studied and are being studied in the framework of ongoing research; authors analyze them from the scientific standpoint, and they are certainly taken into account in the relevant practical recommendations.

In this regard, it is appropriate to recall that such problems as detection, exposure and investigation of crimes committed by convicts in correctional institutions while serving their sentences were considered in detail in the works of V.K. Kolomeits (1969), N.I. Kulagin (1977), A.P. Khalyavin (1978), M.A. Petukhovskii (1979), V.A. Kovalev (1982), V.V. Nikolyuk (1990), N.G. Shurukhnov (1992), S.D. Averkin (2011), S.P. Brylyakov (2013), O.A. Malysheva (2014), A.A. Krymov (2016), V.I. Kachalov (2018), and others. Various aspects of criminal procedure and purely criminalistic activities of authorities and institutions of the penal system are considered in the research works of Ya.I. Gilinskii (1967), A.I. Vasil'ev (1970), I.E. Karasev(1973), V.N. Bibilo (1979), A.I. Minenok (1985), E.V. Reitenbakh (1995), O.V. Voronin (2004), K.A. Sinkin (2004), I.V. Pastukhov (2005), O.P. Aleksandrova (2006), A.V. Grishchenko (2006), A.M. Lyutynskii (2006), S.A. Birmamitova (2007), V.A. Gnatenko (2007), A.V. Strakhov (2007), E.R. Pudakov (2008), A.A. Kamardina (2012), S.L. Mirolyubov(2012), O.V.Guzhva(2013), A.A. Nuzhdin (2014), Yu. A. Tyabina (2016), A.Yu. Antipov (2017), L.L. Santashova (2017), and some others. These very researchers deserve credit for theoretical substantiation and scientific interpretation of the fact that the functioning of penal institutions and bodies includes, among other things, criminal procedure and criminalistics. Moreover, almost all of them in their works unanimously note that employees of penal institutions and bodies clearly do not apply enough effort to use criminalistic knowledge and implement criminal procedure powers; thus, it negatively affects the functioning of the Russian penal system as a whole. Often, its officials turn out to be insufficiently prepared for the practical implementation of both purely procedural and diverse criminalistic activities. The most tangible related consequence is that prison offenders manage to avoid criminal liability for their new illegal actions. All this clearly shows that the need for an effective mechanism to manage criminal procedure and criminalistic activities of Russian penal institutions and bodies not only remains a pressing issue, but has also become one of the major present-day tasks that require a speedy solution. We consider it quite obvious that this problem can be solved only if officials of FSIN 
Russia acquire relevant professional competencies. Let us try and substantiate this idea.

It is well known that criminal procedure and criminalistic knowledge are in demand, first of all, in the work of law enforcement officers. Educational literature on criminology often clarifies this position with reference to specific law enforcement agencies designed to identify, disclose, investigate and prevent crimes [12, p. 13]. However, penal institutions and bodies are almost never mentioned in this context, despite the fact that they are part of the pool of Russian law enforcement agencies. Despite the fact that so far there is no legally established list of such agencies, their purpose, functions, system, structure and tasks are well known to every lawyer, since they are considered within the framework of the academic discipline "Law enforcement agencies", which is taught in all higher educational institutions for legal studies [7, p. 22]. Moreover, specially authorized officials of Russian penal institutions carry out intelligence-gathering activities, in the framework of which they detect, investigate and suppress illegal intentions of suspects, defendants and convicts held in pre-trial detention centers and correctional facilities. Basically, the purpose of penal institutions is to implement current Russian penal legislation (hereinafter $\mathrm{RPL}$ ), which sees their major tasks not only in enforcing punishment as such, but also in the prevention of new crimes and prison-related offences. However, it is not yet possible to recognize unconditionally the fact that penal institutions have a full-fledged function of preliminary investigation. This is due to the fact that certain provisions of the RF CPC regulating criminal procedure activities of institutions, bodies and officials of the Federal Penitentiary Service of Russia are inconsistent and lack specificity.

Thus, according to Paragraph 1 of Part 1 of Article 40 and Paragraph 5 of Part 2 of Article 157 of the RF CPC, penal institutions and bodies have the procedural status of agencies of inquiry, which should assume the presence of definite powers to receive, register and verify reports of crimes in accordance with Article 144 of the RF CPC, to make a final procedural decision in accordance with Article 145 of the RF CPC (on initiation of criminal proceedings, on refusal to initiate criminal proceedings, on sending materials for investigation in accordance with the jurisdiction), to perform urgent investigative actions in accordance with Article 157 of the RF CPC, etc. However, law enforcement practice in this area is still very controversial, because the Federal Penitentiary Service of Russia lacks its own investigative jurisdiction, and the Instruction of the General Prosecutor of the Russian Federation of October
25, 2013 No. 456/69 "On strengthening prosecutor's supervision of procedural activities of penal institutions and bodies" (hereinafter - the instruction) actually acknowledges the fact that the institutions and bodies of FSIN Russia are not full-fledged bodies of inquiry. Granted, it partly recognizes the established practice of receiving, reviewing and resolving reports of crimes by institutions and bodies of FSIN Russia. At the same time, the instruction, to put it mildly, does not approve of their making any procedural decisions, except, perhaps, for the transfer of materials of preliminary investigation according to investigative jurisdiction, within the time limit established by law. As for urgent investigative actions, which in accordance with Paragraph 5 of Part 2 of Article 157 of the RF CPC can be conducted by prison governors after the decision on the initiation of criminal proceedings has been adopted, prosecutors should first establish the exceptional circumstances that made the prison governor initiate criminal proceedings to conduct urgent investigative actions. As a result, the prosecutor's office, despite RF CPC instructions, does not consider prison governors as a full-fledged inquiry body, but allows them to initiate criminal proceedings for urgent investigative actions. The situation is aggravated by the fact that local bodies of inquiry and preliminary investigation usually do not initiate criminal proceedings in relation to the crime committed or being prepared for commission on the territory of a correctional facility until they receive an official notification about it and pre-investigation review materials collected on the relevant occasion and transferred to them under investigative jurisdiction from a specific correctional institution.

Having studied criminal cases of prison-related offences we see that in addition to reports, explanations and various kinds of background information collected at the stage of checking the report of the crime, case files contain inspection records of the crime scene, examinations, and reports of viewing security camera footage. Case files also contain orders to conduct forensic examinations, though quite rarely. Thus, corrections officers, when reviewing reports of crimes committed or being prepared by convicts, regularly carry out various verification actions, but at the same time the main supervisory authority of the country does not perceive them as independent and fully capable inquiry bodies. One cannot and should not put up with this practice, and even more so recognize it as being in line with the letter of the law, in particular, because such an attitude, at least, raises doubts as to whether corrections officers should acquire the knowledge, skills and abilities they need at the initial stage of crimi- 
nal proceedings. Moreover, in their daily work, they almost constantly have to apply the knowledge that has been generated by the science of criminology for two centuries already. Suffice it to mention the daily personality identification of convicts serving their sentences (during general checks, checks at checkpoints, etc.), description of their appearance and prominent physical characteristics in suspect profiles, fingerprinting and placing these persons on various criminalistic records, implementation of identification photography, audio and video recordings and analysis of their materials.

It is also necessary to note the importance of detecting and using smell traces in the activities of security officers in general, and dog handlers of correctional institutions, in particular. They engage in training and daily use of working dogs for inspection of vehicles that leave the territory of correctional institutions, for patrolling internal restricted areas of protected facilities, for searching for and detention of convicted escapees, for searching for and detection of narcotic drugs, explosives, firearms and ammunition, and for the implementation of intelligence-gathering activities, security and preventive measures. It has long been noticed that a dog handler with a working dog exerts an important psychological impact on offenders through his/her appearance and behavior, forcing them to abandon their criminal intentions [8]. Many correctional institutions are creating banks of smell traces of convicts who fall under preventive registration measures. For example, UFSIN Russia for the Republic of Mordovia and UFSIN Russia for the Kaluga Oblast have accumulated positive experience in discovering cell phones in the territory of correctional institutions by smell [2]. Now it is actively implemented in the work of canine units of correctional institutions of other territorial bodies $[1 ; 5 ; 6]$.

The importance of working dogs for each correctional institution is also confirmed by the fact that when investigating prison-related crimes, the investigator or inquirer may well need the help of a dog handler from the correctional institution in the course of investigative actions [9]. Moreover, the results of intelligence-gathering activities and regime measures available to penal institutions and bodies are usually crucial for an objective and comprehensive investigation of prison offenses. This is quite natural, since the circumstance in proof in a prison-related crime has a number of features arising out of the subjective side and the subject of the crime, as well as the types of harm caused by such crimes. Its most important component is the establishment of circumstances that characterize the consequences of a criminal act, since all crimes under such a combination of circumstances neces- sarily become habitual. Knowledge and understanding of the specifics of the subject and limits of evidence allows the inquirer, investigator, and then the court to investigate and resolve specific criminal cases correctly, without infringing on the rights and legitimate interests of convicts, to combat crime consistently and purposefully in their environment with the help of legal means, and to conduct effective preventive work. In this case, the following circumstances have their own specific features and are subject to establishment and proof: place of the crime (determines the time and nature of the new actions of the convict); method of committing illegal actions, and other circumstances that affect the environment of the crime; identity of the victim; identity of the suspect; circumstances that contributed to the commission of the crime.

According to the current legislation, the results of intelligence-gathering activities and regime measures of penal institutions and bodies cannot be regarded as evidence in criminal cases, but they can contribute to the formation of a high-quality evidence base and the correct organization of the proof process itself, thus ensuring the effectiveness of procedural and, first of all, investigative actions. Taking into account these circumstances, we believe that the materials of criminal cases on prison-related offences, in addition to the relevant resolutions and protocols of investigative actions, should include documents drawn up by corrections officers and containing the information that would promote a full, objective and comprehensive investigation.

In order for such documents to acquire evidentiary value, the correctional officers who compose them must have a clear understanding of when, how and what actions they need to take in cases of prison offenses, how to interact with the bodies of inquiry and preliminary investigation, what factors negatively affecting the investigation of prison crimes may occur in a particular investigative situation, how they can neutralize their consequences, and so on. Despite the obvious points of contact between the practice of execution of sentences and pre-trial proceedings on criminal cases and the recommendations of criminalistic science, many correctional officers do not seek to acquire much-needed professional competencies in the field of criminal procedure and criminalistics, believing that they are important only for those representatives of Russian law enforcement agencies who directly carry out preliminary investigation or inquiry in the framework of their main official duties. The transition of departmental educational institutions to a two-level training system and new federal state educational standards did not correct this situation, but rather aggravated it, since starting in 
2011, the amount of academic time allocated for studying these subjects at the higher education institutions of the Federal Penitentiary Service of Russia was significantly reduced. Moreover, if the course in Criminal Process lost a relatively small number of academic hours, then the course in Criminology was reduced by almost a half.

Another negative factor is that currently the territorial investigation and inquiry bodies do not have any specialization in the investigation of prison-related crimes. It is important to note that in the Soviet period of Russian history, the situation in this regard was completely different, since then there was a corps of investigators of forest correctional labor institutions (ULITU) and investigators under prosecutor's offices for monitoring the observance of laws in correctional labor institutions (ITU) [14, p. 114]. Long gone are the days when the penal system was part of the Ministry of Internal Affairs, which showed at least some interest in investigation of prison crimes. Accordingly, investigators and inquirers of internal affairs agencies, whose jurisdiction under the current legislation includes most types of prisonrelated offences, no longer see the need to specialize in their investigation, since they do not engage in it regularly, but once in a while.

It is gratifying to note that against the background of departmental disunity, scientific interest in the problems of investigation of prison crimes has not only remained, but is gradually increasing. It is evidenced by the considerable number of defended dissertations and published scientific papers on this topic that have emerged over the past two decades. Some of their authors conclude that it is necessary to allocate and further develop a special area of criminalistic knowledge. V.V. Nikolaychenko, for example, was the first to raise the question concerning the feasibility of forming a "private criminalistic theory of punitive crime, which will be the basis for the development and application of means and methods of investigation and prevention of crimes committed by persons with a criminal record". He sees its task in "highlighting" the criminally significant consequences of the application of criminal punishment [4, p. 23]. About a decade after him, V.S. Ishigeev and I.P. Parfinenko, participating in an international research-to-practice conference, started a discussion on the independent nature of the doctrine of penitentiary criminology. In their works, they highlighted distinctive features of prison offences and described the approximate content of criminalistic teaching they propose [3, p. 358]. Examples like these can be continued.

At the same time, we have to acknowledge the presence of certain negative facts that occur with regard to further scientific elaboration of in- vestigation of prison-related crimes. According to the monitoring of dissertations defended on such issues, we can say that since 2000 the academic community have seen new research findings on this topic being produced almost every year; however, recently, the extent of scientific elaboration of such problems has decreased dramatically. Over the past five years, virtually no dissertations have been defended on the investigation of prison-related crimes.

It is important to note that of all types of educational organizations and academic institutions that have the potential to carry out research on the investigation of prison offences, it is the universities of the Federal Penitentiary Service of Russia that conduct the bulk of such research. In this regard, we should note the contribution of professors N.G. Shurukhnov and A.A. Krymov, who are now at the helm of scientific schools that once originated in the Academy of the Federal Penitentiary Service of Russia ("Investigation and prevention of prisonrelated crimes", "Criminal procedure activities of the bodies and institutions of the penal system"); the scholars also initiate and conduct active work on the introduction of procedural and criminalistic competencies in the professional activities of employees of FSIN Russia. A large number of dissertations addressing specific criminal procedure and criminalistic problems that emerge in the activities of penal institutions have been prepared and defended under the scientific guidance of the scholars [11].

We should note that in recent years there have been many positive changes in the procedure and conditions for the execution of criminal penalties. However, a number of important tasks in this area still need to be addressed. One of them is the formation of new and multiplication of existing professional competencies in employees of institutions and bodies of FSIN Russia.

The main conclusions that we came to while studying the problem of formation of criminal procedure and criminalistic professional competencies of corrections officers of the Federal Penitentiary Service of Russia are as follows.

1. The need for these competencies is due to objective necessity to implement the goals and objectives of correctional institutions.

2. The low interest in the formation of the criminal procedure and criminalistic competences in corrections officers of FSIN Russia and the lack of demand for such competencies on the part of employees of the penal system is connected on the one hand with the fact that FSIN Russia has no subdivisions that would exercise preliminary investigation functions, on the other hand - with the lack of departmental interest of other law enforcement agencies (except the Federal Peni- 
tentiary Service of Russia) toward specialization of the investigation of prison-related crimes.

3. An analysis and understanding of the system of professional training of employees for correctional institutions of FSIN Russia, as well as a review of law enforcement practice, allows us to come to the conclusion that there is no universal unified way to form criminal procedure and criminalistic competencies in employees of the penal system. Addressing this issue requires a comprehensive approach under which it is not enough only to adjust departmental education in higher education institutions of FSIN Russia by increasing the number of class hours allocated to the disciplines "Criminal procedure", "Criminalistics", and adjusting the course schedules to add instructions on how officers should act with regard to the commission of a prison-related crime and its investigation. In personal conversations, officers of FSIN Russia express the following suggestions:

- the need to introduce special courses within the framework of basic departmental education, which provide for the study of specific issues of officers' activities related to the commission of a prison-related crime and its investigation;

- the development of specialized advanced training courses for corrections officers;

- expanding the scientific understanding of the problems of criminal procedure and criminalistics that arise in the practice of functioning of correctional institutions, and using the obtained knowledge to work out the most concise, but intuitive and visual algorithms for the actions of correctional officers at the preliminary stage of investigation of prison-related crimes, as well as sample documents necessary for documenting the illegal activities of convicts.

\section{REFERENCES}

1. Characteristics of persons held in correctional colonies for adults. FSIN Russia: official website. Available at: http://fsin.gov. ru/structure/inspector/iao/statistika/Xar-ka\%20lic\%20sodergahixsya \%20v\%20IK/ (accessed October 28, 2020). (In Russ.). 2. Shurukhnov N.G. Kriminalistika: ucheb. posobie [Criminalistics: textbook]. Moscow: Yurist”, 2005. 639 p.

3. Stoiko N.G. Pravookhranitel'nye organy: uchebnik [Law enforcement agencies: textbook]. Moscow: Yurait, 2019.518 p. 4. Tevosyan A.T. On the introduction of the term "canine detachment" in the activities of the canine unit of the penal system. In: III Mezhdunarodnyi penitentsiarnyi forum "Prestuplenie, nakazanie, ispravlenie" (k 20-letiyu vstupleniya v silu Ugolovnoispolnitel'nogo kodeksa Rossiiskoi Federatsii): sbornik tezisov vystuplenii i dokladov uchastnikov (g. Ryazan', 21-23 noyab. 2017 g.): $v 8$ t. T. 7: Materialy kruglykh stolov "Osushchestvlenie operativno-rozysknoi deyatel'nosti v uchrezhdeniyakh UIS na sovremennom etape", "Nauka i praktika v obespechenii rezhima v penitentsiarnykh uchrezhdeniyakh", "Kinologicheskoe obespechenie deyatel'nosti FSIN Rossii: teoreticheskie osnovy i prakticheskii opyt" [Third international penitentiary forum "Crime, punishment, reformation" (commemorating the 20th anniversary of the entry into force of the Criminal Executive Code of the Russian Federation): collection of abstracts of speeches and reports of participants (Ryazan, November 21-23, 2017): in 8 volumes. Volume 7: Proceedings of round tables "Implementation of intelligence-gathering activities in penal institutions at the present stage", "Science and practice in ensuring the regime in penal institutions", "Cynological support of the Federal Penitentiary Service of Russia: theoretical foundations and practical experience"]. Ryazan: Akademiya FSIN Rossii, 2017. Pp. 425-428. (In Russ.). 5. In the Department of the Federal Penitentiary Service of Mordovia dog handlers have been training working dogs for the search of cellular phones. Official website of UFSIN Russia in the Republic of Mordovia. Available at: http://info-rm. com/2012/10/31/v-ufsin-mordovii-kinologi-proshli.html (accessed September 11, 2020). (In Russ.).

6. Colleagues from Chuvashia adopt best practices of UFSIN Mordovia. Available at: http://www.13.fsin.su/news/detail. php?ELEMENT ID=54871 (accessed September 11, 2020). (In Russ.).

7. In UFSIN Pskov there is a dog trained to search for mobile phones. Official website of UFSIN Russia in the Pskov Oblast. Available at: http://60.fsin.su/news/detail.php?ELEMENT_ID= 114533 (accessed August 24, 2020). (In Russ.).

8. Five mobile phones were found by a working dog in a correctional facility in Primorye. Website of the news of Primorsky Krai. Available at: http://primpress.ru/article/24258 (accessed September 11, 2020). (In Russ.).

9. Fomin Yu.S. Problems of investigating the penitentiary crimes in present-day conditions. Vestnik Permskogo universiteta. Yuridicheskie nauki=Perm University Herald. Juridical Sciences, 2012, no. 4, pp. 204-209. (In Russ.).

10. Shurukhnov N.G. Rassledovanie i preduprezhdenie prestuplenii, sovershaemykh osuzhdennymi $v$ ispravitel'notrudovykh uchrezhdeniyakh: dissertatsiya na soiskanie uchenoi stepeni doktora yuridicheskikh nauk [Investigation and prevention of prison-related crimes: Doctor of Sciences (Law) dissertation]. Moscow, 1991. 475 p.

11. Shurukhnov N.G. Classification of forensic techniques of crime investigation, its theoretical and practical value. Vestnik Tomskogo gosudarstvennogo universiteta = Tomsk State University Journal, 2020, no. 450, pp. 252-256. (In Russ.).

12. Nikolaichenko V.V. Penitentsiarnye i postpenitentsiarnye prestupleniya: kriminalisticheskaya teoriya i praktika: dissertatsiya na soiskanie uchenoi stepeni doktora yuridicheskikh nauk [Prison-related crimes and re-offending after release: criminalistic theory and practice: Doctor of Sciences (Law) dissertation]. Saratov, 2006. 453 p.

13. Shurukhnov N.G., Meretskii N.E., Ishigeev V.S. Some causes and conditions of manifest excesses of authority by penitentiary employees: unlawful acts against inmates. Vserossiiskii kriminologicheskii zhurnal = Russian Journal of Criminology, 2019, vol. 13, no. 5, pp. 772-781. (In Russ.).

14. Ishigeev V.S., Parfinenko I.P. Revisiting the issue concerning the creation of the doctrine of penal criminalistics. In: Deyatel'nost' pravookhranitel'nykh organov v sovremennykh usloviyakh: sb. materialov XXII mezhdunar. nauch. -prakt. $k o n f . V 2 t$. [Activities of law enforcement agencies in modern conditions: proceedings of the 22nd international scientificpractical conference. In 2 volumes]. Irkutsk: FGKOU VO VSI MVD Rossii, 2017. Volume 1. Pp. 358-361. (In Russ.).

\section{INFORMATION ABOUT THE AUTHORS}

ALEKSANDR S. SHATALOV - Doctor of Sciences (Law), Professor of the Department of Criminal Procedure and Criminalistics, Academy of the Federal Penitentiary Service of Russia, Ryazan, Russian Federation. ORCID: https://orcid. org/0000-0001-9696-416X, e-mail: asshatalov@rambler.ru

ALEKSANDR V. AKCHURIN - Candidate of Sciences (Law), Associate Professor, Head of the Department of Criminal Procedure and Criminalistics, Academy of the Federal Penitentiary Service of Russia, Ryazan, Russian Federation. ORCID: https://orcid.org/0000-0003-1742-1162, e-mail: 79206310258@yandex.ru 